医療安全とシミュレーション

RRS と医療安全

安宅一晃*1 中川雅史 ${ }^{* 2}$

[要旨] 近年, 院外心停止の蘇生率の改善は著しい. しかし, 院内心停止の生存率は改善していな い. これら患者の多くが数時間前に症状の悪化が認められている. この変化を捉え, 対応すれば予 期せぬ心停止は防ぎ得る. 欧米ではRapid Response System(RRS)が一気に広まった. RRS の構成としては, 単に早く対応するチームではなく，4つの要素 ; (1) Afferent limb(気づき : 病 棟), (2) Efferent limb(対応チーム: RRT [Rapid Response Team], MET [Medical Emergency Team])，(3)データ管理・解析部門，(4)管理部門，を構築してお互いに有機的につなげる 必要がある.

キーワード : Rapid Response System, Patient safety, 院内心停止

\section{はじめに}

心肺蘇生法の標準化と蘇生教育が盛んに行われる ようになり，その結果として院外の心停止における 予後の改善に関する報告は多い ${ }^{1)}$. 2). しかし, 病院内 における心停止の自己心拍再開率や予後に関しては 2013年の報告でもわずかな改善にとどまっている33. それは院内心停止(IHCA : in-hospital cardiac arrest）では基礎疾患が関与していることが多く，心 静止や無脈性電気活動(PEA) が多いからであると されている. また 60 〜 $80 \%$ 症例で心停止前になん らかの所見を示していると報告された ${ }^{4)}$. この時点 で適切な対応をする Rapid Response System(RRS) が考えられた。米国では2005年から 2006 年にかけ て, 米国医療の質改善研究所(IHI : Institute for Healthcare Improvement)により推進された国家プ ロジェクトでRRSが提唱され，医療の質を劇的に

${ }^{* 1}$ 奈良県立医科大学付属病院医療安全推進室

*2 紀南病院麻酔科
向上させてきた ${ }^{5) ~ 8)}$. 最近日本においても各種学会 や研究会でRRSのことが取り上げられ，注目され ている。ここではRRSの概要および，従来の心停 止の対応とはどう違うのか, 特に医療安全の側面か ら概説する。

\section{I 気づき}

心停止は意識なし，呼吸なし，脈なしのいわゆる 死の 3 兆候で, 判断しやすくかつ評価者による差は ほとんどない。一方，状態悪化のバイタルサインは 判断には, 経験の浅い看護師や医師と経験豊かな看 護師や医師とでは当然違いが生じることになる。こ の状況を改善するためには異常であるというバイ夕 ルサインの基準作りが重要になってくる。ABCDE アプローチに準じた基準を作ることによって見落と しなく評価できる(表 1)。呼吸数は全身状態悪化の 一番初めのサインとされている ${ }^{8)}$.しかし，その測
著者連絡先 安宅一晃

干 $634-8522$ 奈良県橿原市四条町 840 奈良県立医科大学付属病院 医療安全推進室 


\section{表 1 院内救急システム (RRS) 起動基準 (医療安全全国共同行動より)}

\begin{tabular}{lll}
\hline 1. & 心拍数 & $\mathrm{HR}<40$ または $>130 \mathrm{bpm}$ \\
2. & 収縮期血圧 & $\mathrm{SBP}<90 \mathrm{mmHg}$ \\
3. & 呼吸回数 & $\mathrm{RR}<8$ または $>28$ 回 / 分 \\
4. & 経皮酸素飽和度 & $\mathrm{SpO}_{2}<90 \%$ \\
5. & 意識の変容 & \\
6. & 尿量の低下 & $<50 \mathrm{ml} / 4 \mathrm{hr}$ \\
7. & 上記以外でなにか変である \\
\hline
\end{tabular}

定には血圧や酸素飽和度 $\left(\mathrm{SpO}_{2}\right)$ に比べて手間がか かる上に，測定時間などが一定しないという問題が ある. $\mathrm{SpO}_{2}$ が簡便に測定できるようになったため に，一般病棟の成人では呼吸数が測定されていない ことが多くなっている。呼吸の評価として $\mathrm{SpO}_{2}$ で 代用することが一般的になっているが，実は違うも のということを認識する必要がある。このように基 準を作っても，正確に評価するトレーニングが必要 となってくる. RRSがどのような患者を対象にし ているのかについて院内に周知しておく必要があ る。心停止した症例を対象にした “Code Blue” で はない点が重要なポイントとなる(表2) ${ }^{9}$.

\section{RRSの構成(図 1)}

RRSは4つのコンポーネントから構成される。急 変患者を認識し, RRSを起動させる部分が afferent limb と呼ばれる部分である。病棟での起動基準を満 たした症例が認識された場合，コールされるチーム がMedical Emergency Team(MET)あるいは Rapid Response Team(RRT)である.MET/RRTによる評 価・対応は efferent limbといわれる。これら afferent limb と efferent limbが適切に稼㗢すればRRSは問 題ないと考えられるが，心停止した症例と違い，そ の評価法，コールのタイミング，報告法，MET/ RRT の到着までの時間，対応などそれぞれにフィー ドバックが必要である。RRSの中には afferent limb と efferent limbへ効果的なフィードバックをする部 門の設置が重要である。この部門は administration $\operatorname{limb}$ といわれる管理部門である。さらに，このよ うにRRSを構築してどのような効果があったかの 判定が必要となる. 院内の予期せ女心停止数, ICU への緊急入室数，院内死亡率などであるが，これら のデータを管理する部門の設置も必須である。これ はdata collection and analysis limbといわれ，デー 夕集積部門である。この管理部門とデー夕集積部門 は日本では医療安全部門が対応することが多い。こ の4つの部門がそれぞれ有機的に連携できて初めて RRSが出来上がる. RRS というと, 集中治療や救 急の医師と看護師によるチームを編成して，心停止 より少し前にコールしてくださいという周知で終わ つてしまうことが多いが，根本的に患者評価，組織 編成など心停止のときの “Code Blue”とは相違が あることを認識することが重要である。そこが曖昧 なまま組織構成すると, 院内は混乱し，早期に呼ば れず成果も期待できない。実際，大阪市立総合医療 センターでCritical Care Outreach (CCO)でRRSを 開始しても，コールされる患者の $10 \%$ 程度の患者 は集中治療部への搬送と判断されなかった(図2). RRSにより今まで見過ごされていた $10 \%$ の患者を 見つけることができた，RRSの導入による効果は Chan らのメ夕解析によると, RRS 導入により ICU 外の院内心停止数は減少するとされている ${ }^{10)}$.

\section{III 医療安全の問題}

RRS は院内重症患者, 特に術直後の変化の激し い患者には有効なシステムである。しかし，そのシ ステム構築にもいくつかの問題点がある点は前項で 述べた。まず，システム構築する以前の根本的な問 題が解決されていない。それは院内の心停止数, 予 期せ女心停止数の把握ができていない病院が非常に 多いことである．院内死亡数を把握している病院は 多い，しかし，心停止数となると統計がないのが大 多数である。予期せ女心停止となると，その定義も 明確なものがないために統計はまったくない.多く の病院はそのような状態であるため, 院内心停止や 
表2 コードブルーとRRSの違い

\begin{tabular}{|c|c|c|}
\hline & コードブルー & RRS \\
\hline チーム起動 & 意識なく, 脈・呼吸なし & $\begin{array}{c}\text { 血圧低下, 頻脈, 呼吸数増加, } \\
\text { 意識変容 }\end{array}$ \\
\hline 対象疾患 & $\begin{array}{c}\text { 心停止, 呼吸停止, } \\
\text { 気道閉塞 }\end{array}$ & $\begin{array}{c}\text { 敗血症, 肺水腫, 不整脈, } \\
\text { 呼吸不全, アナフィラキシー }\end{array}$ \\
\hline チーム構成 & $\begin{array}{c}\text { 麻酔科, 救急部, ICU, 内科 } \\
\text { 医師 - 看護師 }\end{array}$ & $\begin{array}{c}\text { ICU 医師・看護師, 呼吸療法士, } \\
\text { 内科医 }\end{array}$ \\
\hline $\begin{array}{c}\text { 呼び出し回数 } \\
\text { (回/1000 入院患者) }\end{array}$ & $0.5 \sim 5$ & $20 \sim 40$ \\
\hline 対応時間 (分) & $>30$ & $20 \sim 30$ \\
\hline 院内死亡率 (\%) & $70 \sim 90$ & $0 \sim 20$ \\
\hline
\end{tabular}

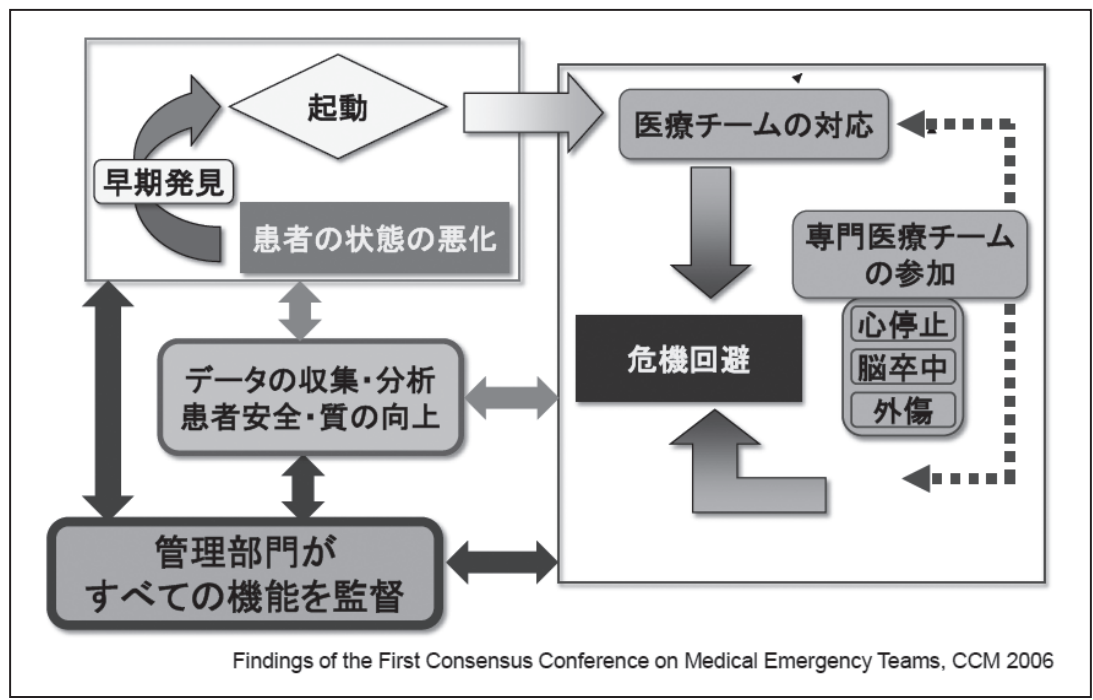

図 1 Rapid Response System

〔高橋りょう子: 大阪大学医学部附属病院 $\mathrm{HP}$ (http:/ www.hosp.med.osaka-u. ac.jp/home/hp-cqm/ingai/seminar/pdf/2009/013_takahashi_handai.pdf) より引用】

RRS 起動の統計に関して全国レベルの調査はされ ていない。これに対してわれわれは2013年から院 内心停止(成人, 小児), $\mathrm{RRS}$ 起動(成人, 小児)に ついての調査を開始したが，まだ十分なデータが集 まっておらず，解析までには至っていない，今後, さらに大きなデー夕集積が必要だと考える ${ }^{11}$.また, 設備面でも院内標準時計の整備, 救急カートの統一 化などといったものも十分とは言えない. 例えば各
部署の時計が数分ずれていることで心停止の起こっ た時間と蘇生が始まった時間が反対になることが起 こり，このままでRRSを始めても統計処理できな くなる可能性もある。こうした院内の統計や設備の 整備をしていかないと, 結局効果的な判定ができな いままRRSは構築され，結果的に活用されないま まで終わってしまう可能性がある. 今後, 複数の学 会レベルでの普及活動が必要である. 


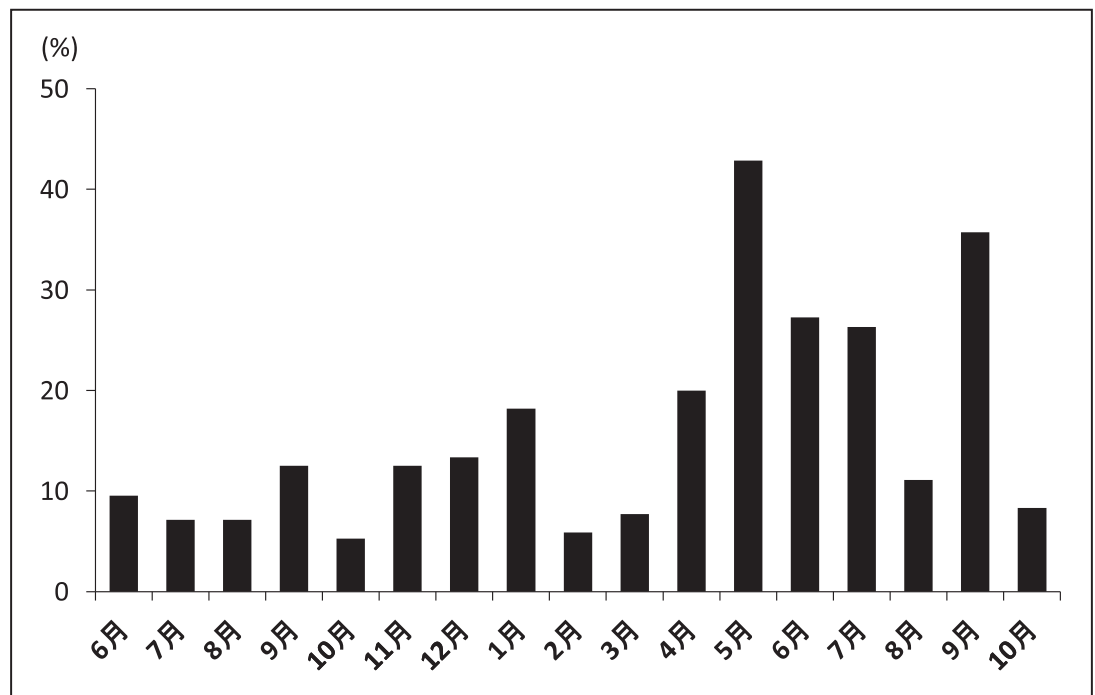

図2 大阪市立総合医療センターにおけるRRTラウンド患者のICU 収容率 (CCO 方式)

\section{参考文献}

1) Wissenberg M, Lippert FK, Folke F, et al. : Association of national initiatives to improve cardiac arrest management with rates of bystander intervention and patient survival after out-of-hospital cardiac arrest. JAMA 310 : 1377-1384, 2013

2) Kitamura T, Iwami T, Kawamura T, et al. : Nationwide improvements in survival from out-of-hospital cardiac arrest in Japan. Circulation $126: 2834-2843$, 2012

3) Morrison LJ, Neumar RW, Zimmerman JL, et al. : Strategies for improving survival after in-hospital cardiac arrest in the United States : 2013 consensus recommendations : a consensus statement from the American Heart Association. Circulation 127 : 15381563, 2013

4) Van Voorhis KT, Willis TS : Implementing a pediatric rapid response system to improve quality and patient safety. Pediatr Clin North Am 56 : 919-933, 2009
5) Kohn LT, Corrigan JM, Donaldson MS : To Err Is Human : Building a Safer Health System. Committee on Quality of Health Care in America, Institute of Medicine ed. National Academy Press, Washington DC, 1999

6) IHI : Overview of the 100,000 Lives Campaign. 2006.(http:// www.ihi.org/offerings/Initiatives/PastStrategicInitiatives/ 5MillionLivesCampaign/Documents/Overview\% 20of\% 20 the $\%$ 20100K\% 20Campaign.pdf)

7) IHI : 5 Million Lives Campaign. 2008. (http://www.ihi. org/IHI/Programs/Campaign)

8）安宅一晃, 藤谷茂樹監訳 : FCCS プロバイダーマニュア ル(第 2 版).メディカル・サイエンス・インターナショ ナル, 東京, 2013

9) Jones DA, DeVita MA, Bellomo R : Rapid-response teams. N Engl J Med 365 : 139-146, 2011

10) Chan PS, Jain R, Nallmothu BK, et al. : Rapid Response Teams : A Systematic Review and Meta-Analysis. Arch Intern Med 170: 18-26, 2010

11) http://hospital-em.net 


\title{
Rapid Response Systems as a Patient Safety Measure
}

\author{
Kazuaki ATAGI*1, Masashi NAKAGAWA*2 \\ ${ }^{* 1}$ Division of Patient Safety and Quality, Nara Medical University \\ ${ }^{* 2}$ Department of Anesthesia, Kinan Hospital
}

Attention was drawn to the safety of patients in acute care hospitals in the early 1990s when studies found large numbers of potentially preventable deaths. Errors were initially ascribed to individual doctors and nurses, but later it was recognised that errors were mainly related to the failure of systems rather than individuals. Rapid-response systems (RRSs) were created to improve recognition of and response to deterioration of patients in general hospital wards, with the goal of reducing the incidence of cardiorespiratory arrest and hospital mortality. An RRS generally has 4 components, namely, an afferent limb, efferent limb, administrative limb, and a data collection and analysis limb.

Key Words : Rapid Response System, Patient safety, In-hospital cardiac arrest

The Journal of Japan Society for Clinical Anesthesia Vol.35 No.4, 2015 